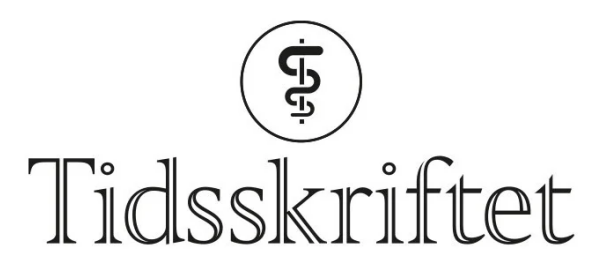

DEN NORSKE LEGEFORENING

\title{
Starter puberteten tidligere enn før?
}

\author{
KRONIKK
}

\section{NINNIE OEHME}

ninnie.oehme@uib.no

Ninnie Oehme er lege i spesialisering ved Barne- og ungdomsklinikken, Haukeland universitetssjukehus og ph.d.-stipendiat ved Universitetet i Bergen.

Forfatteren har fylt ut ICMJE-skjemaet og oppgir ingen interessekonflikter.

\section{INGVILD SARVOLD BRUSERUD}

Ingvild Særvold Bruserud er sykepleier med master i helse- og sosialfag, ph.d.-stipendiat ved Universitetet i Bergen og Barne- og ungdomsklinikken, Haukeland universitetssjukehus. Forfatteren har fylt ut ICMJE-skjemaet og oppgir ingen interessekonflikter.

\section{ANDRÉ MADSEN}

André Madsen er molekylærbiolog, ph.d. og postdoktor ved Universitetet i Bergen. Forfatteren har fylt ut ICMJE-skjemaet og oppgir ingen interessekonflikter.

\section{PÉTUR BENEDIKT JÚLÍUSSON}

Pétur Benedikt Júlíusson ph.d., avdelingsdirektør ved Avdeling for helseregisterforskning og utvikling ved Folkehelseinstituttet, overlege ved Barne- og ungdomsklinikken, Haukeland universitetssjukehus og professor ved Klinisk institutt 2, Universitetet i Bergen. Forfatteren har fylt ut ICMJE-skjemaet og oppgir ingen interessekonflikter.

\section{Om vi kommer tidlig eller sent inn i puberteten, kan ha langtidsvirkninger på helsen. Vi vet ikke nok om hva som induserer pubertet og hvilke faktorer som påvirker dens} start. 


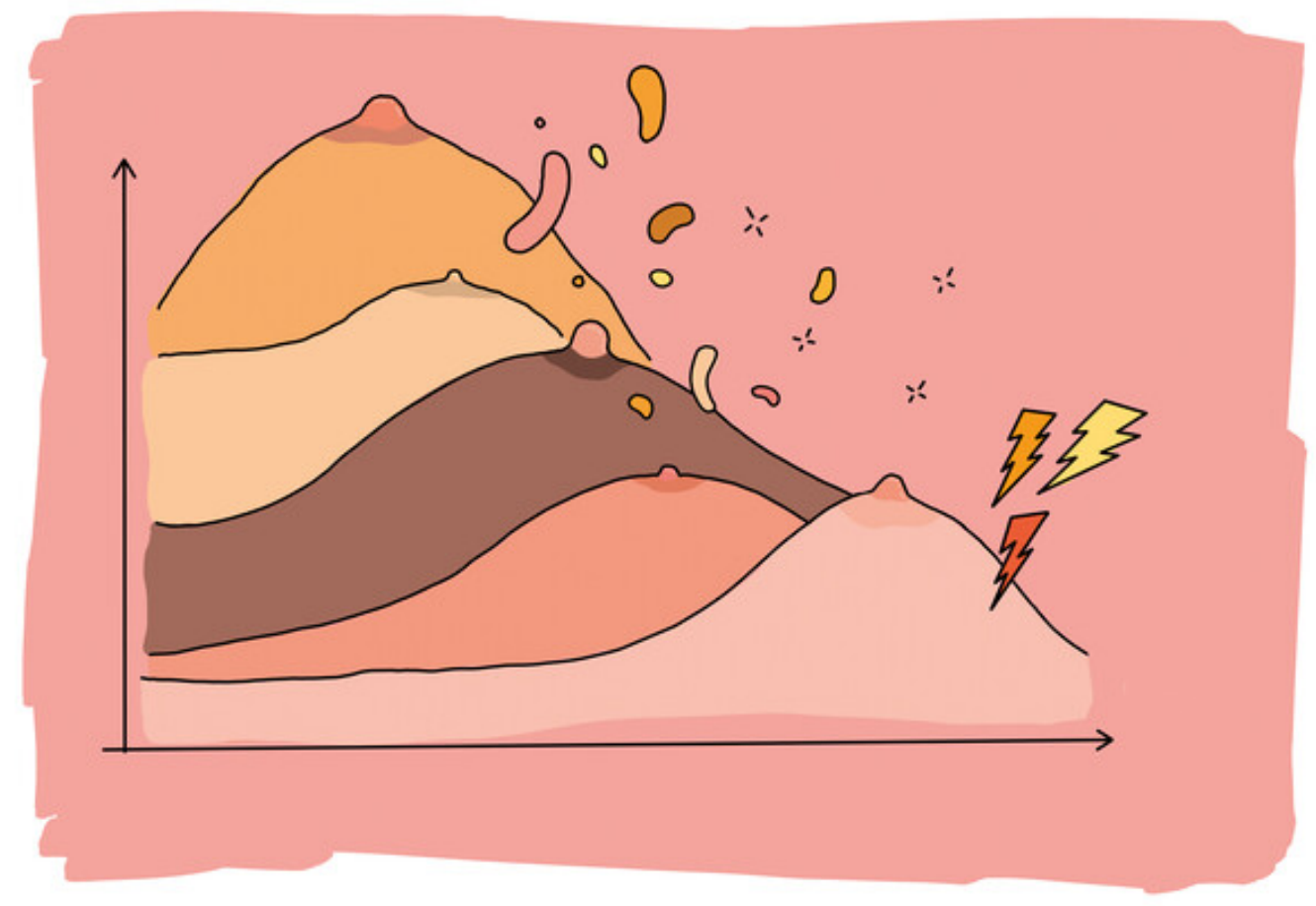

Illustrasjon: Sylvia Stølan

I løpet av de siste tre tiårene har studier fra Europa og USA vist en tendens til tidligere pubertetsstart hos jenter, med en større endring i tidspunktet for begynnende brystmodning enn første menstruasjon (menarke) $(\mathbf{1}, \underline{2})$. Forandring i pubertetsalder for gutter har vært mer tvetydig (3), men noen studier har vist lignende tendenser (4). Det er foreslått at denne sekulære trenden skyldes overvekt (5) og/eller hormonforstyrrende kjemikalier ( $\underline{6})$.

Det kan være vanskelig å gjennomføre pubertetsstudier. Undersøkelsene er intime, og det er utfordrende å få rekruttert et representativt utvalg av friske individer i den aktuelle aldersgruppen. For jenter er det enkelt å spørre om tidspunkt for første menstruasjon, men dette er et sent pubertetstegn. Pubertetsvurdering av jenter bør derfor inkludere vurdering av brystutvikling, da knopping av brystet definerer pubertetsstart (Tanners stadium B2). Pubertetsstart hos gutter defineres ved at testikkelvolumet av minst én testikkel er $\geq 4 \mathrm{ml}$ målt ved sammenlignende palpasjon med et Prader-orkidometer.

Den eneste informasjonen hittil om pubertetsutviklingen i Norge er fra data om menarkealder. Brudevoll og medarbeidere publiserte data for perioden 1861-1974, som viste at gjennomsnittlig menarkealder i Oslo gikk fra 15,6 år i 1861 til 13,3 år i 1940 (.7.). I Norge er det kun rapportert om marginale endringer i alder ved menarke de siste tiårene, med stabil alder like over 13 år siden etterkrigstiden og frem til Vekststudien i Bergen 1(2003-06) (ㅁ).

\section{Ny norsk referanse for pubertetsutvikling}

Vekststudien i Bergen 2 er den første studien i Norge der formålet er å kartlegge og lage referanser for pubertetsutvikling. Nærmere 1200 friske barn og unge i alderen 6-16 år ble rekruttert fra seks ulike skoler i bergensområdet i 2016. Hos jentene ble brystutviklingen vurdert klinisk og med ultralyd, og de ble spurt om menarke. Guttene ble undersøkt med ultralyd for beregning av testikkelvolum. Tanners stadium for pubesbehåring ble vurdert hos begge kjønn. I tillegg ble flere antropometriske mål registrert og blodprøver tatt.

«Resultatene våre kan indikere at $i$ Norge starter puberteten tidligere nå enn for 10-15 år siden» 
Tanners vurdering av brystenes utvikling utføres vanligvis ved klinisk palpasjon og inspeksjon og er spesielt utfordrende hos jenter med overvekt og fedme. Ultralyd kan skille fettvev fra brystkjertelvev og kan derfor være nyttig for pubertetsvurderingen hos overvektige jenter (9.). Vi har identifisert seks ulike stadier av brystutviklingen basert på sammensetningen av fettvev, kjertelvev og bindevev (10 $)$. Pubertetsreferanse basert på ultralydundersøkelse av bryst har aldri tidligere vært publisert. Hos guttene gir bruken av ultralyd muligheten for et mer direkte mål av testikkelvolum, uten påvirkning av omkringliggende strukturer, som for eksempel bitestikkel eller patologi som hydrocele. Testikkelvolumet blir kalkulert som en ellipsoide ut ifra lengde-, bredde- og dybdemål (1ㅡ).

Data fra Vekststudien i Bergen 2 viste at gjennomsnittsalderen for pubertetsstart hos jenter var 10,4 år (Tanners stadium B2), noe som er sammenlignbart med andre nordeuropeiske studier (12). Samtidig observerte vi en signifikant nedgang i menarkealder for hele kohorten fra 13,3 år i den første vekststudien til 12,9 år nå. For jentene med norsk opprinnelse fant vi også en liten, men signifikant nedgang tilsvarende 2,8 måneder. Resultatene våre kan indikere at i Norge starter puberteten tidligere nå enn for 10-15 år siden. Dette funnet bør følges opp med fremtidige studier.

For guttene ble data fra studien vår anvendt til modellering av testikkelvolum ut ifra alder (13). Dette er den første norske publiserte vekstkurven for testikkelvolum, og viser at gjennomsnittlig pubertetsstart inntreffer ved 11,7 år blant friske gutter i Norge. Dette ble også bekreftet med pubertale testosteronverdier (14.). Dette er svært sammenlignbart med pubertetsstart ved 11,6 år, som ble observert hos nederlandske gutter (unders $\varnothing \mathrm{kt}$ med ultralyd i 2007-09) (15) og 11,7 år hos danske gutter (undersøkt med Prader-orkidometer i 2006)(4).

\section{«Tidlig menarke er assosiert med økt dødelighet samt høyere risiko for brystkreft, hjerte- og karsykdommer og psykisk sykdom»}

Normal alder for pubertetsstart foreligger dersom barnets alder er innenfor $-1+2$ standardavvik fra gjennomsnittet. Aldre utenfor dette skal vurderes som henholdsvis tidlig eller sen pubertet. Basert på våre funn fra Vekststudien i Bergen 2 anbefaler vi å opprettholde de nåværende grensene nedfelt i pediatriveilederen på hhv. 8-13,5 år for jenter og 9-14,5 år for gutter (므). I dagens vekstkurver er det pubertetsreferanser fra Danmark (1991-93) som er brukt, og disse planlegges å byttes ut med våre nye norske referanser. Her foreligger det ikke store endringer hos guttene, men dagens jenter modnes noe tidligere.

\section{Hva påvirker tidspunkt for pubertetsstart?}

Faktorene som påvirker pubertetsstart er mange og sammensatte. Genetikk antas å forklare 50-75\% av variasjonen, mens resten tilskrives omgivelsesfaktorer som ernæring, generell helse, psykososialt stress, perinatale faktorer, kroppssammensetning og miljøfaktorer, som hormonforstyrrende kjemikalier (므). Trenden mot tidligere pubertet er gjerne sett i sammenheng med den parallelle overvektsepidemien blant unge. Tidligere studier om hormonforstyrrende kjemikalier som årsak til tidligere pubertetsstart satte innledningsvis søkelys på tiden umiddelbart før pubertet. Nyere studier viser at hendelser i føtal- og nyfødtperiode også er viktige. Effekten av ulike stressfaktorer avhenger av perioden med forekomst og eksponering. For eksempel kan prepubertal underernæring eller overernæring ( $\varnothing \mathrm{kt}$ fettmasse) hos jenter føre til henholdsvis forsinket eller tidlig pubertet $(\underline{17}, \underline{18})$, mens intrauterin veksthemming er assosiert med tidlig pubertet (19).). Psykososialt

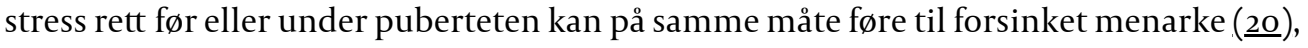
mens fremskyndet pubertet er beskrevet hos jenter som opplever slik stress i tidlig

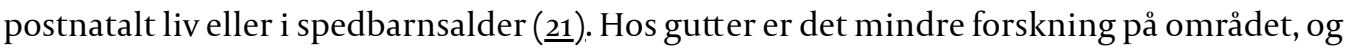
man vet derfor lite om hva som påvirker deres tidspunkt for pubertetsstart.

\section{Konsekvenser av tidligere pubertetsstart}


Tidlig pubertet har spesielt hos jenter blitt assosiert med uheldige konsekvenser for senere helse. På populasjonsnivå har man sett at tidlig menarke er assosiert med økt dødelighet (22) samt høyere risiko for brystkreft (23), hjerte- og karsykdommer (244) og psykisk sykdom (25). I tillegg har tidlig pubertet vist å være assosiert med hyppigere ungdomsrelatert risikoadferd som varer over lengre tid $(\underline{26}, \underline{2} 7$.$) . Hos gutter er det derimot få studier som$ viser til helsemessige konsekvenser av tidlig pubertet. Det er funnet en beskyttende effekt

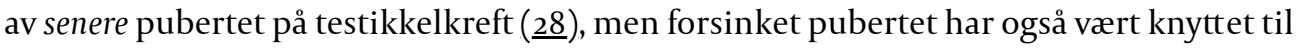
mobbing, dårlig selvtillit og psykososial engstelse (29.).

Alder for pubertetsstart er derfor et viktig aspekt for den norske folkehelsen. Vår forskning har til hensikt å se om kroppssammensetning og/eller forekomst av hormonforstyrrende kjemikalier i blodet kan påvirke pubertetsstart og -utvikling med å se på gode objektive mål på sekundær kjønnsutvikling og hormonprofiler og videre utforske genetiske mekanismer.

\section{LITTERATUR}

1. Aksglaede L, Sørensen K, Petersen JH et al. Recent decline in age at breast development: the Copenhagen Puberty Study. Pediatrics 2009; 123: e932-9. [PubMed][CrossRef]

2. Eckert-Lind C, Busch AS, Petersen JH et al. Worldwide secular trends in age at pubertal onset assessed by breast development among girls: A systematic review and meta-analysis. JAMA Pediatr 2020; 174: e195881. [PubMed][CrossRef]

3. Juul A, Teilmann G, Scheike T et al. Pubertal development in Danish children: comparison of recent European and US data. Int J Androl 2006; 29: 247-55, discussion 286-90. [PubMed][CrossRef]

4. Sørensen K, Aksglaede L, Petersen JH et al. Recent changes in pubertal timing in healthy Danish boys: associations with body mass index. J Clin Endocrinol Metab 2010; 95: 263-70. [PubMed] [CrossRef]

5. Reinehr T, Roth CL. Is there a causal relationship between obesity and puberty? Lancet Child Adolesc Health 2019; 3: 44-54. [PubMed][CrossRef]

6. Parent AS, Franssen D, Fudvoye J et al. Developmental variations in environmental influences including endocrine disruptors on pubertal timing and neuroendocrine control: Revision of human observations and mechanistic insight from rodents. Front Neuroendocrinol 2015; 38: 12-36. [PubMed] [CrossRef]

7. Brudevoll JE, Liestøl K, Walløe L. Menarcheal age in Oslo during the last 140 years. Ann Hum Biol 1979; 6: 407-16. [PubMed][CrossRef]

8. Júlíusson PB, Roelants M, Eide GE et al. Vekstkurver for norske barn. Tidsskr Nor Legeforen 2009; 129: 281-6. [PubMed][CrossRef]

9. Carlson L, Flores Poccia V, Sun BZ et al. Early breast development in overweight girls: does estrogen made by adipose tissue play a role? Int J Obes 2019; 43: 1978-87. [PubMed][CrossRef]

10. Bruserud IS, Roelants M, Oehme NHB et al. Ultrasound assessment of pubertal breast development in girls: intra- and interobserver agreement. Pediatr Radiol 2018; 48: 1576-83. [PubMed] [CrossRef]

11. Oehme NHB, Roelants M, Bruserud IS et al. Ultrasound-based measurements of testicular volume in 6- to 16-year-old boys - intra- and interobserver agreement and comparison with Prader orchidometry. Pediatr Radiol 2018; 48: 1771-8. [PubMed][CrossRef]

12. Bruserud IS, Roelants M, Oehme NHB et al. References for ultrasound staging of breast maturation, Tanner breast staging, pubic hair and menarche in Norwegian girls. J Clin Endocrinol Metab 2020; 105: 1599-607. [PubMed][CrossRef]

13. Oehme NHB, Roelants M, Saervold Bruserud I et al. Reference data for testicular volume measured with ultrasound and pubic hair in Norwegian boys are comparable with Northern European populations. Acta Paediatr 2020; 109: 1612-9. [PubMed][CrossRef]

14. Madsen A, Oehme NB, Roelants M et al. Testicular ultrasound to stratify hormone references in a cross-sectional Norwegian study of male puberty. J Clin Endocrinol Metab 2020; 105: dgzog4. [PubMed][CrossRef]

15. Goede J, Hack WW, Sijstermans Ket al. Normative values for testicular volume measured by ultrasonography in a normal population from infancy to adolescence. Horm Res Paediatr 2011; 76: 5664. [PubMed][CrossRef] 
16. Norsk barnelegeforening. Pediatriveiledere. 2.4 Normal pubertet.

https://www.helsebiblioteket.no/retningslinjer/pediatri/endokrinologi/normal-pubertet Lest 16.4.2020.

17. Dunger DB, Ahmed ML, Ong KK. Early and late weight gain and the timing of puberty. Mol Cell Endocrinol 2006; 254-255: 140-5. [PubMed][CrossRef]

18. Ong KK, Ahmed ML, Dunger DB. Lessons from large population studies on timing and tempo of puberty (secular trends and relation to body size): the European trend. Mol Cell Endocrinol 2006; 254255: 8-12. [PubMed][CrossRef]

19. Ibáñez L, Jiménez R, de Zegher F. Early puberty-menarche after precocious pubarche: relation to prenatal growth. Pediatrics 2006; 117: 117-21. [PubMed][CrossRef]

20. Tahirović HF. Menarchal age and the stress of war: an example from Bosnia. Eur J Pediatr 1998; 157: 978-8o. [PubMed][CrossRef]

21. Wierson M, Long PJ, Forehand RL. Toward a new understanding of early menarche: the role of environmental stress in pubertal timing. Adolescence 1993; 28: 913-24. [PubMed]

22. Charalampopoulos D, McLoughlin A, Elks CE et al. Age at menarche and risks of all-cause and cardiovascular death: a systematic review and meta-analysis. Am J Epidemiol 2014; 180: 29-40. [PubMed][CrossRef]

23. Collaborative Group on Hormonal Factors in Breast Cancer. Menarche, menopause, and breast cancer risk: individual participant meta-analysis, including 118964 women with breast cancer from 117 epidemiological studies. Lancet Oncol 2012;13:1141-51. [PubMed][CrossRef]

24. Lakshman R, Forouhi NG, Sharp SJ et al. Early age at menarche associated with cardiovascular disease and mortality. J Clin Endocrinol Metab 2009; 94: 4953-6o. [PubMed][CrossRef]

25. Mendle J, Ryan RM, McKone KMP. Age at Menarche, Depression, and Antisocial Behavior in Adulthood. Pediatrics 2018; 141: e20171703. [PubMed][CrossRef]

26. Stattin H, Kerr M, Skoog T. Early pubertal timing and girls' problem behavior: integrating two hypotheses. J Youth Adolesc 2011; 40: 1271-87. [PubMed][CrossRef]

27. Patton GC, McMorris BJ, Toumbourou JW et al. Puberty and the onset of substance use and abuse. Pediatrics 2004; 114: e300-6. [PubMed][CrossRef]

28. Maule M, Malavassi JL, Richiardi L. Age at puberty and risk of testicular cancer: a meta-analysis. Int J Androl 2012;35: 828-34. [PubMed][CrossRef]

29. Golub MS, Collman GW, Foster PM et al. Public health implications of altered puberty timing. Pediatrics 2008; 121 (suppl 3): S218-30. [PubMed][CrossRef]

Publisert: 31. august 2020. Tidsskr Nor Legeforen. DOI: 10.4045/tidsskr.20.0043

Mottatt 15.1.2020, første revisjon innsendt 24.2.2020, godkjent 16.4.2020.

(C) Tidsskrift for Den norske legeforening 2023. Lastet ned fra tidsskriftet.no 26. april 2023. 